Article

\title{
Synthesis and Gas-Permeation Characterization of a Novel High-Surface Area Polyamide Derived from 1,3,6,8-Tetramethyl-2,7-diaminotriptycene: Towards Polyamides of Intrinsic Microporosity (PIM-PAs)
}

\author{
Giuseppe Genduso ${ }^{1,2}\left(\mathbb{D}\right.$, Bader S. Ghanem ${ }^{1,2}\left(\mathbb{D}\right.$, Yingge Wang ${ }^{2}$ and Ingo Pinnau 1,2,*(D) \\ 1 Functional Polymer Membranes Group, Advanced Membranes and Porous Materials Center, \\ Division of Physical Sciences and Engineering, King Abdullah University of Science and Technology, \\ Thuwal 23955-6900, Saudi Arabia; giuseppe.genduso@kaust.edu.sa (G.G.); \\ bader.ghanem@kaust.edu.sa (B.S.G.) \\ 2 Advanced Membranes, and Porous Materials Center, Division of Physical Sciences and Engineering, \\ King Abdullah University of Science and Technology, Thuwal 23955-6900, Saudi Arabia; \\ yingge.wang@kaust.edu.sa \\ * Correspondence: ingo.pinnau@kaust.edu.sa
}

Received: 18 January 2019; Accepted: 5 February 2019; Published: 19 February 2019

\begin{abstract}
A triptycene-based diamine, 1,3,6,8-tetramethyl-2,7-diamino-triptycene (TMDAT), was used for the synthesis of a novel solution-processable polyamide obtained via polycondensation reaction with 4,4'-(hexafluoroisopropylidene)bis(benzoic acid) (6FBBA). Molecular simulations confirmed that the tetrasubstitution with ortho-methyl groups in the triptycene building block reduced rotations around the $\mathrm{C}-\mathrm{N}$ bond of the amide group leading to enhanced fractional free volume. Based on $\mathrm{N}_{2}$ sorption at $77 \mathrm{~K}, 6$ FBBA-TMDAT revealed microporosity with a Brunauer-Emmett-Teller (BET) surface area of $396 \mathrm{~m}^{2} \mathrm{~g}^{-1}$; to date, this is the highest value reported for a linear polyamide. The aged 6FBBA-TMDAT sample showed moderate pure-gas permeabilities (e.g., 198 barrer for $\mathrm{H}_{2}, \sim 109$ for $\mathrm{CO}_{2}$, and $\sim 25$ for $\mathrm{O}_{2}$ ) and permselectivities (e.g., $\alpha \mathrm{H}_{2} / \mathrm{CH}_{4}$ of $\sim 50$ ) that position this polyamide close to the $2008 \mathrm{H}_{2} / \mathrm{CH}_{4}$ and $\mathrm{H}_{2} / \mathrm{N}_{2}$ upper bounds. $\mathrm{CO}_{2}-\mathrm{CH}_{4}$ mixed-gas permeability experiments at $35^{\circ} \mathrm{C}$ demonstrated poor plasticization resistance; mixed-gas permselectivity negatively deviated from the pure-gas values likely, due to the enhancement of $\mathrm{CH}_{4}$ diffusion induced by mixing effects.
\end{abstract}

Keywords: triptycene diamine; glassy polymers; polyamides; PIM-polyamides; gas separation; mixed-gas permeation; gas sorption; intrinsic microporosity

\section{Introduction}

Polyamides are synthetic macromolecules containing amide groups (-CO-NH-) mainly prepared via polycondensation reaction between diamines and diacid-type monomers. Aromatic and semi-aromatic polyamides have been broadly applied in the industry, due to their extraordinary mechanical, chemical, and thermal properties [1]. For example, aromatic polyamides ("aramids") are in use for the production of synthetic fibers of superior mechanical strength and heat resistance (e.g., Kevlar and Nomex fibers). Another important application of aromatic polyamides is the production of thin-film composite membranes by interfacial polymerization [2] for water desalination via reverse osmosis (RO); the employment of these membranes revolutionized desalination industry by making $\mathrm{RO}$ more cost efficient than conventional energy-intensive thermal processes [3].

Polyamides can be synthesized as fully-crosslinked networks producing surface areas exceeding $500 \mathrm{~m}^{2} \mathrm{~g}^{-1}$ [4-6]. For gas adsorption and gas storage applications, aromatic network polyamides are 
competitive with polymers of intrinsic microporosity (PIMs) [7-9], metal organic frameworks (MOFs), covalent organic frameworks (COFs) [10], porous poly(aryleneethynylene) (PAE) [11], porous aromatic frameworks (PAFs) [12], conjugated microporous polymers (CMPs) [13], and hypercross-linked polymers (HCPs) [14]. Although crosslinked aromatic network polyamides can exhibit high surface areas, they are insoluble and, therefore, cannot be utilized to synthesize integral asymmetric and thin-film composite membranes for gas separations.

Linear, uncrosslinked aromatic polyamides are solution-processable; however, these materials generally display low fractional free volume (generally between $0.14-0.16$ [15]) because interchain hydrogen bonding induces tight chain packing. Hence, gas permeabilities of linear aromatic polyamides are normally lower than those of polycarbonates, polysulfones, polyimides, and other conventional low-free-volume glassy polymers $[15,16]$. On the other hand, gas-pair permselectivities of linear polyamides (particularly for hydrogen applications) are notable; this has led to structural modifications to enhance the gas permeability of linear polyamides [16-33].

Very high gas permeabilities and moderate gas-pair selectivities are displayed by linear PIMs, such as ladder PIMs (e.g., PIM-1) and PIM-PIs (polyimides of intrinsic microporosity) that have attracted significant interest for membrane applications in the past decade [8,34-37]. More recently, the fine-tuning of the sites of contortion of these polymers has strongly improved the performance of these materials establishing the 2015 Robeson upper bound for $\mathrm{O}_{2} / \mathrm{N}_{2}, \mathrm{H}_{2} / \mathrm{N}_{2}$, and $\mathrm{H}_{2} / \mathrm{CH}_{4}$ separations [38]. Moreover, by appropriate selection of functional groups (e.g., -OH, $-\mathrm{COOH}$ ) PIM-PIs have also defined the recently introduced 2018 mixed-gas upper bound for $\mathrm{CO}_{2} / \mathrm{CH}_{4}$ separation [37].

Likewise, the inclusion of bulky contortion sites-e.g., spirobifluorene, ethanoanthracene, Tröger's base-, or triptycene-based moieties-in the repeat unit of aromatic polyamides [25,39] might pave the way toward the design of the PIM-polyamides (PIM-PAs) class of materials (i.e., polyamides of enhanced free volume and gas permeability). One of the earliest attempts was pursued by Weber et al. [9] who employed a spirobifluorene building block to synthesize a linear polyamide containing microporosity (Brunauer-Emmett-Teller surface area of $156 \mathrm{~m}^{2} \mathrm{~g}^{-1}$ was reported). The use of a Tröger's base building block for the synthesis of linear aromatic polyamides was also reported in the literature [40].

Synthesis of linear polymers of high free volume can be successfully achieved by using the triptycene (Figure 1) building block [41-45] that is a member of the iptycene family [46], characterized by the presence of $[2,2,2]$ bicyclic bridges linked together by three arene rings. The nonplanar conformation of the triptycene unit frustrates efficient polymer chain packing promoting the formation of free volume [47]. Moreover, this building block presents a peculiar paddle-wheel-like conformation that further improves the free volume of the polymeric matrix, due to a steric effect; in fact, triptycenes are large moieties characterized by a structurally fixed internal free volume (IFV)—as indicated in blue in Figure 1. Although triptycene-based linear polyamides were previously described in the literature [48-55], none of these studies aimed to fine-tune the properties of these polymers, in order to produce attractive combinations of gas permeability and permselectivity for industrial gas separation applications.

In this work, we synthesized a new, linear, and solution-processable polyamide of intrinsic microporosity (PIM-PA) obtained via polycondensation reaction of $o$-tetramethyldiamino-triptycene (TMDAT) with 4,4'-(hexafluoroisopropylidene)bis(benzoic acid) (6FBBA)—see Scheme 1a. The 6FBBA-TMDAT polyamide was characterized by: ${ }^{1} \mathrm{H}$ NMR, Fourier transform infrared (FTIR), thermogravimetric analysis (TGA), wide-angle X-ray diffraction (WXRD), Brunauer-Emmett-Teller (BET) surface area, and molecular dynamics simulations. The pure- and mixed-gas transport properties of 6FBBA-TMDAT are reported to assess its potential for membrane-based gas separations. 

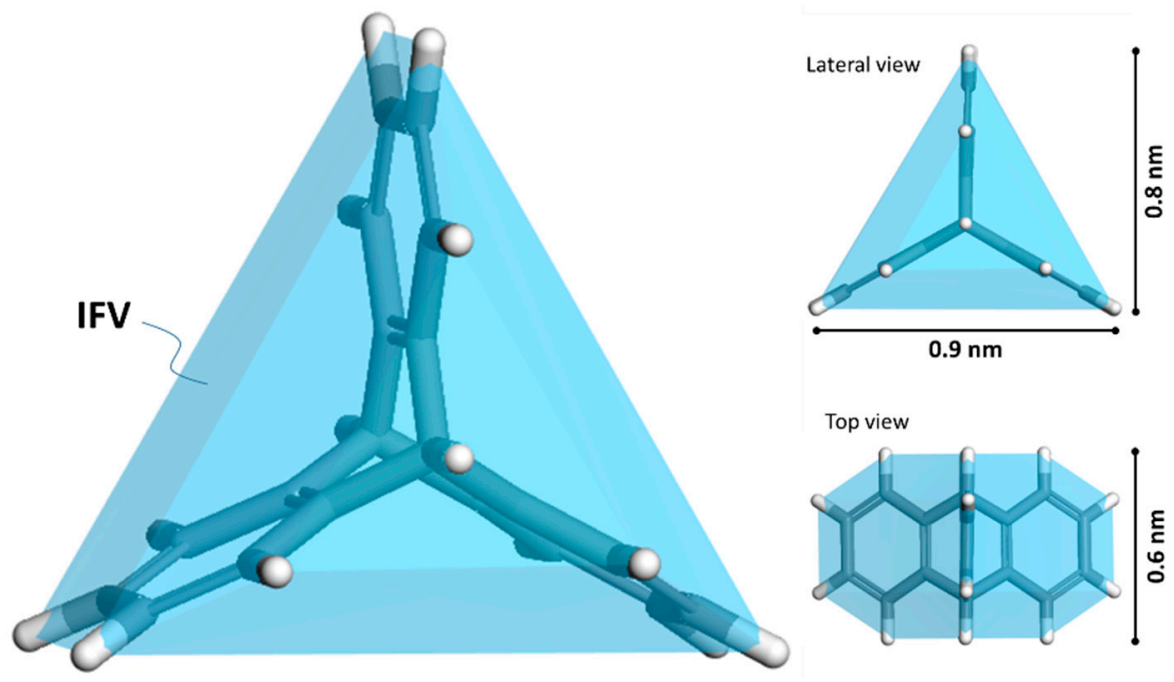

Figure 1. 3D visual of a triptycene building block (dimensions are also provided based on molecular dynamic simulation).

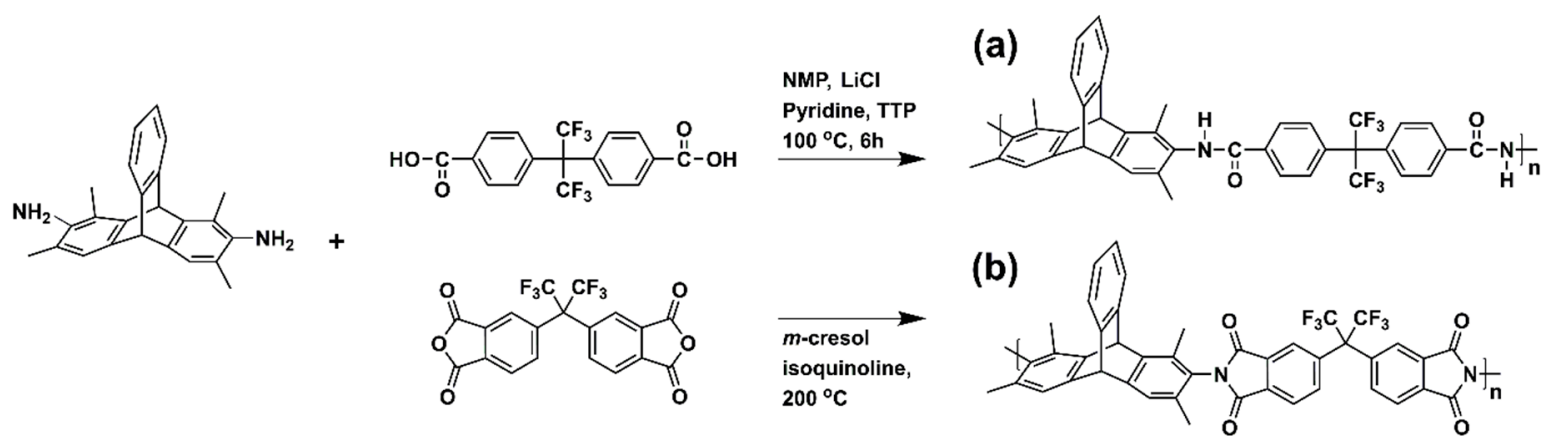

Scheme 1. Synthesis scheme of: (a) 6FBBA-TMDAT polyamide and (b) 6FDA-TMDAT polyimide [45].

A recently reported structurally related polyimide [45] derived from TMDAT and 4,4'(hexafluoroisopropylidene)diphthalic anhydride (6FDA) is shown in Scheme 1b. Here, we demonstrated that the hydrogen-bonding effects of the amide linkages in 6FBBA-TMDAT induced significant differences in polymer packing and gas transport properties compared to 6FDA-TMDAT polyimide.

\section{Materials and Methods}

\subsection{Materials}

Anhydrous $N$-methyl-2-pyrrolidone (NMP), N,N-dimethylacetamide (DMAC), anhydrous tetrahydrofuran (THF), pyridine, and triphenylphosphite (TPP) were purchased from Sigma Aldrich (St. Louis, MO, USA). Anhydrous lithium chloride was purchased from Sigma Aldrich and dried under vacuum at $160{ }^{\circ} \mathrm{C}$ for $10 \mathrm{~h}$ before use. 4,4'-(Hexafluoroisopropylidene)bis(benzoic acid) (6FBBA) was purchased from Sigma Aldrich and dried under vacuum at $80^{\circ} \mathrm{C}$ before use. $1,3,6,8-$ Tetramethyl-2,7-diamino-triptycene (TMDAT) was prepared according to the procedure reported by Ghanem et al. [45].

\subsection{Characterization Methods}

Proton nuclear magnetic resonance spectrum $\left({ }^{1} \mathrm{H}\right.$ NMR) was recorded on a Bruker (Billerica, MA, USA) DRX 400 spectrometer. Chemical shifts $(\delta)$ are reported in parts per million (ppm) and referenced to tetramethylsilane. FTIR measurements were carried out with a Varian (Santa Clara, CA, USA) 610-IR FTIR spectrometer. The viscosity of a $20 \mathrm{wt} \%$ solution of 6FBBA-TMDAT polyamide in 
NMP was measured with a Brookfield (Middleboro, MA, USA) CAP 2000 cone-and-plate viscometer at $450 \mathrm{rpm}$. Wide-angle X-ray diffraction (WXRD) was performed on a Bruker D8 Advance diffractometer (Billerica, MA, USA) using a scanning rate of $1 \mathrm{~s} / \mathrm{step}$ with $0.02^{\circ}$ per step ranging from 5 to $50^{\circ}$. The multiple amorphous peaks in the WXRD spectrum were then deconvoluted using Peak Analyzer in Origin software (OriginLab Corporation, Northampton, MA, USA), and the average chain spacing ( $d$-spacing) was calculated with Bragg's law. The thermal degradation temperature of the polyamide was determined by thermogravimetric analysis (TGA, TA Q-5000, TA Instruments, New Castle, DE, USA) under $\mathrm{N}_{2}$ atmosphere at a heating rate of $3^{\circ} \mathrm{C} \mathrm{min}^{-1}$ from room temperature to $800{ }^{\circ} \mathrm{C}$.

A Micromeritics (Norcross, GA, USA) ASAP-2020 was employed to perform BET measurement using nitrogen sorption at $77 \mathrm{~K}$. Before measurement, a 6FBBA-TMDAT powder sample was first dried at $120^{\circ} \mathrm{C}$ under vacuum for $24 \mathrm{~h}$. Micromeritics ASAP 2020 software (v.4.02) was used to calculate the BET surface area. $\mathrm{CO}_{2}$ and $\mathrm{CH}_{4}$ isotherms at $35^{\circ} \mathrm{C}$ in the pressure range 1-15 atm were determined with a gravimetric IGA system (Hiden Isochema, Warrington, UK).

Material Studio 2017 software (BIOVIA, San Diego, CA, USA) was used for the analysis of the torsion energy vs. rotation angle around the amide unit; we imposed: (i) the pcff forcefield, (ii) geometrical optimization, (iii) and ultrafine quality of estimated energies over 360 steps between -180 to $180^{\circ}$ angles. Amorphous cell module calculations ( $p c f f$ forcefield and a number of five polymeric chains of five repetitive units each were chosen were also pursued). We set a probe radius of the Connolly's surface of $1.6 \AA$, and the software estimated the volume of the amorphous cell occupied by the polymer $\left(V_{o c c}\right)$ and the remaining free volume $\left(V_{\text {free }}\right)$; we used this information to calculate the FFV as: $F F V=V_{\text {free }} /\left(V_{\text {free }}+V_{\text {occ. }}\right)$.

\subsection{Polymer Synthesis}

The TMDAT diamine monomer was prepared according to a previously reported procedure in four steps starting from 1,3,6,8-tetramethyl-anthracene, initially prepared from the Friedel-Crafts alkylation reaction between $m$-xylene and dichloromethane in the presence of aluminum chloride [56]. Heating the diazonium salt of 2-aminobenzoic acid with tetramethyl-anthracene in dichloroethane yielded 1,3,6,8-tetramethyl-triptycene. Selective nitration of the tetramethyl-triptycene using potassium nitrate and trifluoroacetic anhydride followed by reduction of the dinitro groups gave the diamine monomer TMDAT [45].

Synthesis of 6FBBA-TMDAT. The 6FBBA-TMDAT polyamide was prepared by the Yamazaki-Higashi phosphorylation polycondensation procedure [57] between equimolar amounts of the commercially available dicarboxylic acid (6FBBA) and the TMDAT diamine monomer in anhydrous NMP as a solvent and using TPP and pyridine as condensing agents (Scheme 1). First, a mixture of TMDAT (0.24 g, $0.705 \mathrm{mmol}), 6$ FBBA (0.277 g, $0.705 \mathrm{mmol}), \mathrm{NMP}(2 \mathrm{~mL}), \mathrm{LiCl}(0.22 \mathrm{~g})$, TPP (0.45 g, $1.45 \mathrm{mmol})$ and pyridine $(0.45 \mathrm{~mL})$ was added to a dry $10 \mathrm{~mL}$ Schlenk tube. After heating in an oil bath for six hours at $120{ }^{\circ} \mathrm{C}$ under a nitrogen atmosphere, the clear viscous solution was cooled and slowly added to methanol $(200 \mathrm{~mL})$ to precipitate the polymer. The resulting white fibrous polymer was collected by filtration, washed several times with methanol and hot water and then purified by re-precipitation from a DMAc/methanol mixture. Finally, drying under vacuum at $130{ }^{\circ} \mathrm{C}$ for $20 \mathrm{~h}$ gave a white fibrous material (90\% yield). FT-IR $\left(v, \mathrm{~cm}^{-1}\right)$ : 3286 (amide N-H stretching), 3028, 3062 (aromatic C-H stretching), 2925 (aliphatic C-H stretching), 1657 (amide carbonyl stretching), 1526, 1491 (aromatic $\mathrm{C}=\mathrm{C}$ ring stretching), 1249 (asymmetric $\mathrm{C}-\mathrm{O}-\mathrm{C}$ stretching), 1020 (symmetric $\mathrm{C}-\mathrm{O}-\mathrm{C}$ stretching), 1136 (C-F stretching). ${ }^{1} \mathrm{H}$ NMR (DMSO- $\left.d_{6}, 400 \mathrm{MHz}, \delta \mathrm{ppm}\right): 2.08(\mathrm{~s}, 6 \mathrm{H}), 2.36(\mathrm{~s}, 6 \mathrm{H}), 5.51(\mathrm{~s}, 1 \mathrm{H}), 6.08$ $(\mathrm{s}, 1 \mathrm{H}), 7.00$ (br. m, 2H), $7.21(\mathrm{~s}, 2 \mathrm{H}), 7.44-7.54(\mathrm{~m}, 6 \mathrm{H}), 8.05(\mathrm{~d}, 4 \mathrm{H}), 9.81(\mathrm{~s}, 2 \mathrm{H})$. BET surface area $=$ $396 \mathrm{~m}^{2} \mathrm{~g}^{-1}$. TGA analysis under $\mathrm{N}_{2}$ atmosphere: Initial weight loss, due to thermal degradation commenced at $T_{d} \sim 450{ }^{\circ} \mathrm{C}$. Dynamic viscosity of a $20 \mathrm{wt} \%$ solution of 6FBBA-TMDAT in NMP was $2.68 \pm 0.03 \mathrm{~g} \mathrm{~cm}^{-1} \mathrm{~s}^{-1}$ (three measurements). 


\subsection{Film Preparation}

6FBBA-TMDAT films were obtained from DMAc solution ( $5 w / v \%$ ) by slow evaporation of the solvent at $80{ }^{\circ} \mathrm{C}$ from a leveled and covered glass Petri dish under a nitrogen stream. The 6FBBA-TMDAT films were further dried at $120^{\circ} \mathrm{C}$ and later soaked in methanol for $48 \mathrm{~h}$, air-dried and then post-dried at $130^{\circ} \mathrm{C}$ under vacuum for $24 \mathrm{~h}$. The absence of residual solvent was confirmed by TGA analysis. The resulting film had a thickness of about $73 \mu \mathrm{m}$, which was measured by a digital micrometer (Mitutoyo (Aurora, IL, USA) 547-400S with an accuracy of $0.00381 \mathrm{~mm}$ ). Effective permeation area values were determined from coupon scan and image analysis. The sample tested for pure-gas permeabilities was aged up to 132 days (methane permeability was also tested after 200 days) upon storage under vacuum in a desiccator. Geometrical density was determined from the average of five weight and area measurements on a fresh sample at $22^{\circ} \mathrm{C}$.

\subsection{Pure- and Mixed-Gas Permeation Coefficients}

The constant-volume/variable-pressure technique [58] was used to observe pure-gas permeabilities of $\mathrm{He}, \mathrm{H}_{2}, \mathrm{~N}_{2}, \mathrm{O}_{2}, \mathrm{CH}_{4}$, and $\mathrm{CO}_{2}$. The same technique was also used to determine $\mathrm{CO}_{2}-\mathrm{CH}_{4}$ mixed-gas permeability and selectivity in 6FBBA-TMDAT up to $30 \mathrm{~atm}$ feed pressure, as described by $\mathrm{O}^{\prime}$ Brien at al. [58]. For all tests, the temperature was set at $35^{\circ} \mathrm{C}$. The local slope of experimental permeate pressure vs. time was recorded to calculate pure- and mixed-gas permeabilities from:

$$
P_{i}=10^{10} \frac{y_{i} \cdot V_{\text {perm }} \cdot l}{x_{i} \cdot p_{\text {feed }} \cdot T \cdot R \cdot A} \cdot \frac{d p}{d t}
$$

where $P_{i}$ is the gas permeability in barrer $\left(1\right.$ barrer $\left.=10^{-10} \mathrm{~cm}^{3}(\mathrm{STP}) \mathrm{cm} \mathrm{cm}^{-2} \mathrm{~s}^{-1} \mathrm{cmHg}^{-1}\right), x_{i}$ and $y_{i}$ are feed and permeate mole fractions, respectively (in the case of pure-gas permeability $x_{i}$ and $y_{i}$ are equal to one), $V_{\text {perm }}$ is the permeate volume, $l$ is the thickness of the membrane, $p_{\text {feed }}$ is the feed pressure, $R$ is the universal gas constant, $A$ is the area of the film, and $d p / d t$ is the local slope of permeate pressure vs. time experimental data. Compositions of the permeate mixed-gas were analyzed via an Agilent Technologies (Santa Clara, CA, USA) 3000A Micro GC. During mixed-gas permeability measurement, the ratio of permeate flow to feed flow (stage cut) was always maintained $<1 \%$. Fresh and aged film samples were always degassed in the permeation system under high vacuum for at least $24 \mathrm{~h}$ prior to testing.

\section{Results and Discussion}

\subsection{Polymer Characterization}

The chemical structure of 6FBBA-TMDAT was confirmed by FTIR and ${ }^{1} \mathrm{H}$ NMR spectroscopy. The FTIR spectrum (Figure 2a) showed the characteristic absorption bands of the amide group at frequencies in the range $3150-3410 \mathrm{~cm}^{-1}$ for $-\mathrm{NH}$ stretching and $1657 \mathrm{~cm}^{-1}$ for $\mathrm{C}=\mathrm{O}$ stretching. The aliphatic and aromatic C-H stretching bands appeared at frequencies of 2925 and $3062 \mathrm{~cm}^{-1}$, respectively. In the ${ }^{1} \mathrm{H}$ NMR spectrum of 6FBBA-TMDAT (Figure 2b), the absorption band at $9.81 \mathrm{ppm}$ is assigned to the amide protons $\left(\mathrm{H}^{\mathrm{h}}\right)$, confirming the formation of amide linkages. The protons of the methyl groups $\left(\mathrm{H}^{\mathrm{a}}\right)$ appeared as two singlets at 2.08 and $2.36 \mathrm{ppm}$, whereas the bridgehead protons of the triptycene unit $\left(\mathrm{H}^{\mathrm{b}}\right)$ appeared at 5.51 and $6.08 \mathrm{ppm}$. The aromatic protons $\left(\mathrm{H}^{\mathrm{c}-\mathrm{g}}\right)$ resonated in the range of 7.00-8.05 ppm. 
(a)

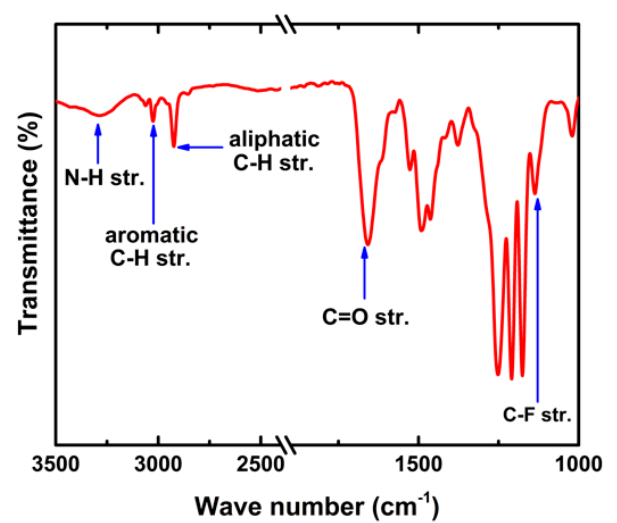

(b)

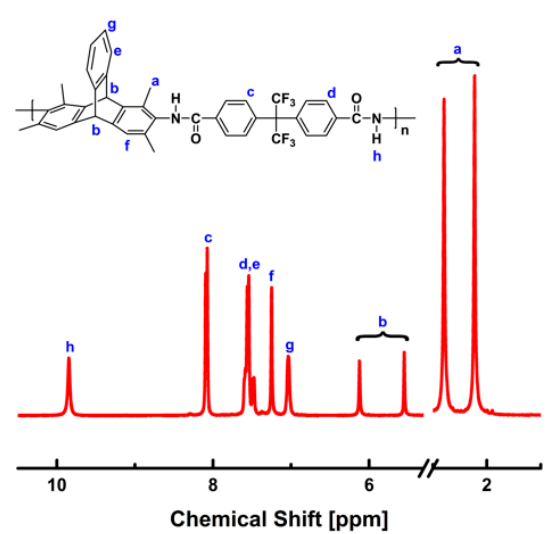

Figure 2. (a) FTIR and (b) ${ }^{1} \mathrm{H}$ NMR spectra of 6FBBA-TMDAT polyamide.

Figure 3 displays the thermogravimetric analysis (TGA) of 6FBBA-TMDAT; the absence of weight loss in the range $100-450{ }^{\circ} \mathrm{C}$ demonstrated that the methanol treatment successfully extracted all DMAc solvent from the 6FBBA-TMDAT sample. The degradation temperature at $5 \%$ weight loss $\left(T_{d, 5 \%}\right)$ was about $480{ }^{\circ} \mathrm{C}$ (Table 1 ); this $T_{d, 5 \%}$ is comparable to that of 6FDA-TMDAT [45] (synthesized by polycondensation of 4,4'-(hexafluoroisopropylidene) diphthalic anhydride (6FDA) and TMDAT) representing the polyimide counterpart of 6FBBA-TMDAT polyamide. TGA was also employed to ensure the absence of any residual solvent in film samples before pure- and mixed-gas permeation tests.

Table 1. Physical properties of 6FBBA-TMDAT polyamide. Degradation temperature at $5 \%$ weight loss $\left(T_{d, 5 \%}\right)$, film density $(\rho)$, surface area $\left(\mathrm{S}_{\mathrm{BET}}\right)$, and fractional free volume $\left.(\mathrm{FFV}) .{ }^{*}\right)$ Data reported for 6FDA-TMDAT polyimide by Ghanem et al. [45]. Fractional free volume (FFV) was calculated for both polymers via molecular modeling (i.e., amorphous cell study in Material Studio 2017 software).

\begin{tabular}{ccccc}
\hline Polymer & $\begin{array}{c}\mathbf{T}_{\boldsymbol{d}, \mathbf{5} \%} \\
{\left[{ }^{\circ} \mathbf{C}\right]}\end{array}$ & $\begin{array}{c}\mathrm{S}_{\text {BET }} \\
{\left[\mathbf{m}^{\mathbf{2}} \mathbf{g}^{-\mathbf{1}}\right]}\end{array}$ & $\begin{array}{c}\boldsymbol{\rho} \\
{\left[\mathbf{g ~ c m}^{-3}\right]}\end{array}$ & $\begin{array}{c}\text { FFV } \\
{[-]}\end{array}$ \\
\hline $\begin{array}{c}\text { 6FBBA-TMDAT } \\
\text { [this work] }\end{array}$ & 480 & 396 & $1.15 \pm 0.04$ & 0.217 \\
6FDA-TMDAT [45] & $470 *$ & $620^{*}$ & $1.13 \pm 0.04$ & 0.254 \\
\hline
\end{tabular}

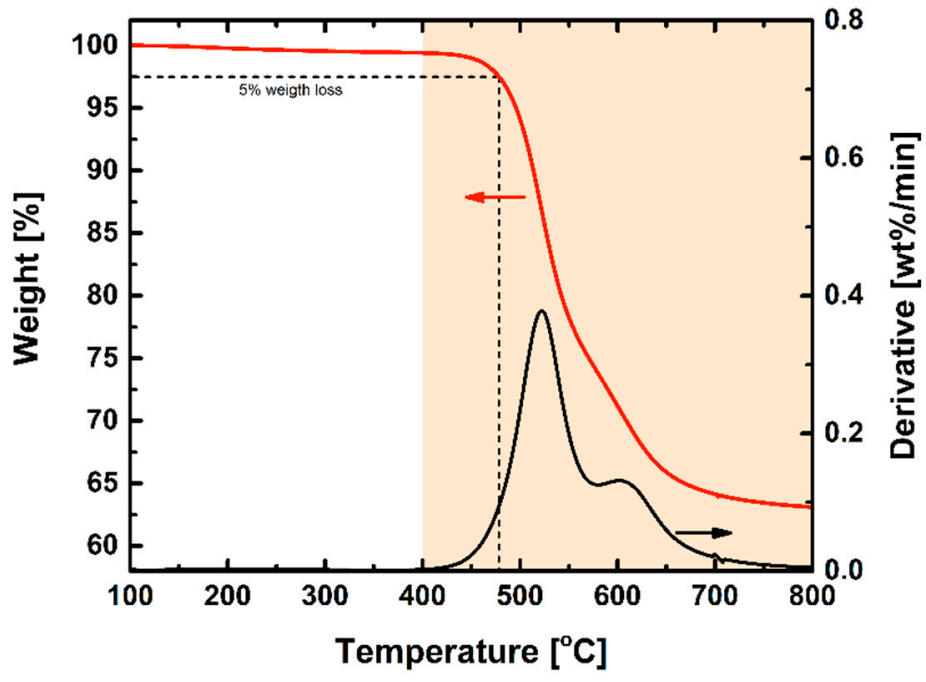

Figure 3. $\mathrm{N}_{2}$ atmosphere TGA analysis of methanol-treated 6FBBA-TMDAT polyamide film dried under vacuum at $130{ }^{\circ} \mathrm{C}$ for $24 \mathrm{~h}$. 
The amorphous cell module of Material Studio 2017 software was applied to simulate the space-filling ability of 6FBBA-TMDAT using the geometric density of 6FBBA-TMDAT measured in-house $\left(1.15 \pm 0.04 \mathrm{~g} / \mathrm{cm}^{3}\right)$. The same simulation procedure was also performed for 6FDA-TMDAT polyimide (see properties in Table 1). Clearly, the amorphous cell of the polyamide (Figure 4a) is more densely packed than that of 6FDA-TMDAT polyimide (Figure 4b); moreover, upon building the amorphous cell, the computer program provided occupied volume $\left(V_{\text {occ. }}\right)$ vs. free volume $\left(V_{\text {free }}\right)$ estimates that were used to calculate the fractional free volume (FFV) of both polymers. Accordingly, the FFV value for 6FBBA-TMDAT was 0.217 (a high value for polyamides) positioning this polyamide at the high end of the range of FFV defined by correlations of gas permeability vs. fractional free volume reported in the classical literature [15]; hence, the insertion of the TMDAT building block was very effective in enhancing the FFV. The 6FDA-TMDAT polyimide showed a higher FFV value of 0.254 ; therefore, we anticipated to observe a higher permeability of this polyimide when compared to the structurally related 6FBBA-TMDAT polyamide, as discussed below.
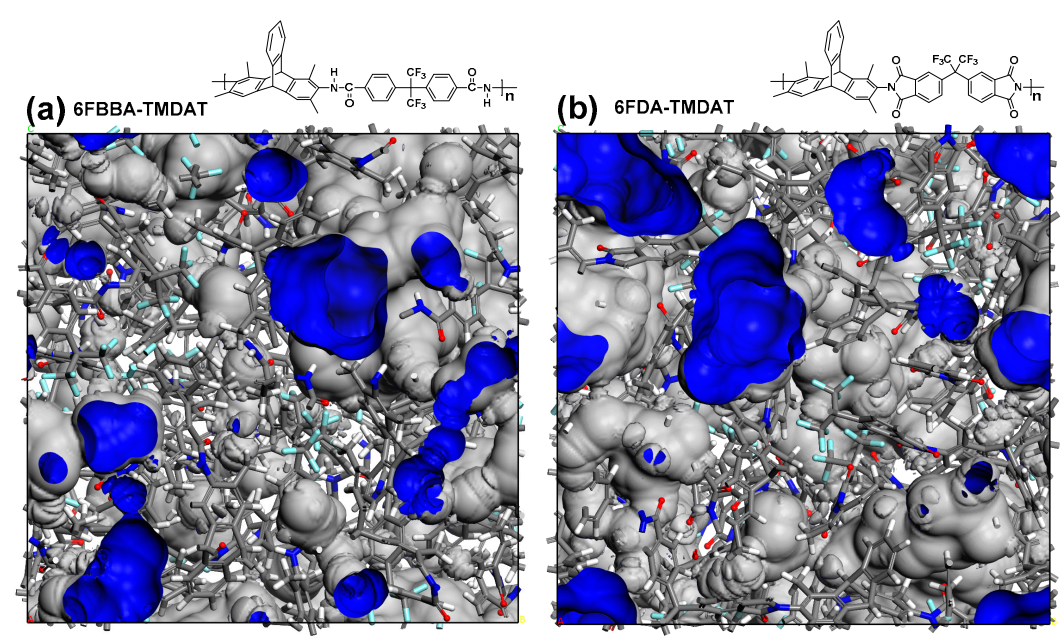

Figure 4. Amorphous-cell simulation of chain packing for: (a) 6FBBA-TMDAT polyamide and (b) 6FDA-TMDAT polyimide.

The difference in FFV between 6FBBA-TMDAT and 6FDA-TMDAT (Table 1) reflects the chain rigidity and chain interaction properties of these polymers. Generally, FFV (and typically gas permeability) increases as the polymer exhibits increased intrachain rigidity and interchain spacing, and shows less interchain interactions (hydrogen bonding or charge transfer complex formation tend to reduce FVV). In particular, chain motion of the 6FBBA-TMDAT polyamide is described here based on a torsion analysis via computer-assisted molecular simulations (Material Studio 2017 program was used). This description was further extended by including a comparison in terms of torsion energy vs. allowed torsion angles between the 6FBBA-TMDAT polyamide and its equivalent 6FDA-TMDAT polyimide. For both polymers, Figure 5a shows the rotational freedom around the C-N bond (1) directly linked to the TMDAT unit. The methyl groups of the TMDAT unit practically lock the rotation to $\sim 120^{\circ}$ for the polyamide and $\sim 180^{\circ}$ for the polyimide; in fact, the hydrogen of the N-H group of the polyamide is located closer to the two methyl groups of the TMDAT than the oxygens of the $\mathrm{C}=\mathrm{O}$ groups of the polyimide. The polyamide can still rearrange itself, due to the rotational freedom around the $\mathrm{C}-\mathrm{N}(2)$ and $\mathrm{C}-\mathrm{C}(3)$ bonds (Figure $5 \mathrm{~b}$ ).

Because of the higher rotational freedom (i.e., lower intrachain rigidity) around the bonds of the amide group, the 6FBBA-TMDAT polyamide can pack its polymeric chains more efficiently than the 6FDA-TMDAT polyimide. $\mathrm{N}_{2}$ sorption at $77 \mathrm{~K}$ (Figure 6) confirmed the simulation results; in fact, $\mathrm{N}_{2}$ uptake in the 6FDA-TMDAT polyimide was higher than in the 6FBBA-TMDAT polyamide; the BET surface area of 6FDA-TMDAT polyimide $\left(620 \mathrm{~m}^{2} \mathrm{~g}^{-1}\right)$ was $\sim 57 \%$ higher than that of 
6FBBA-TMDAT polyamide. Nevertheless, because of the presence of the tetra-substituted triptycene block, the 6FBBA-TMDAT polyamide showed a surprisingly high BET surface area of $396 \mathrm{~m}^{2} \mathrm{~g}^{-1}$.
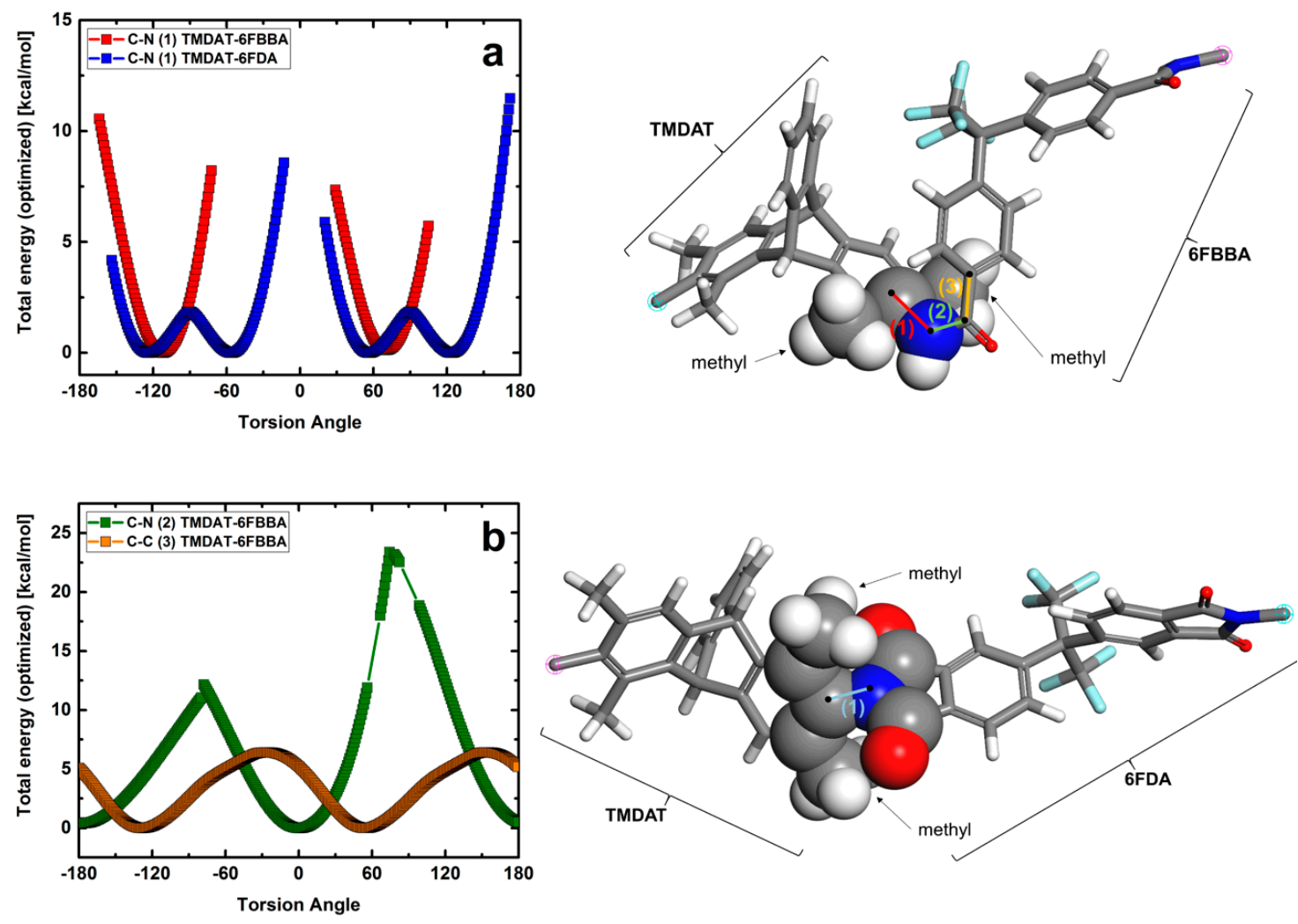

Figure 5. Torsion energy vs. torsion angle for the amide group of the 6FBBA-TMDAT (three dihedral angles) and for the single dihedral angle of the imide group of the 6FDA-TMDAT (polyimide). Rotation freedom around: (a) The C-N (1) bond of both 6FBBA-TMDAT and 6FDA-TMDAT; (b) for the remaining $\mathrm{C}-\mathrm{N}(2)$ and $\mathrm{C}-\mathrm{C}(3)$ bonds of the amide group of the polyamide.

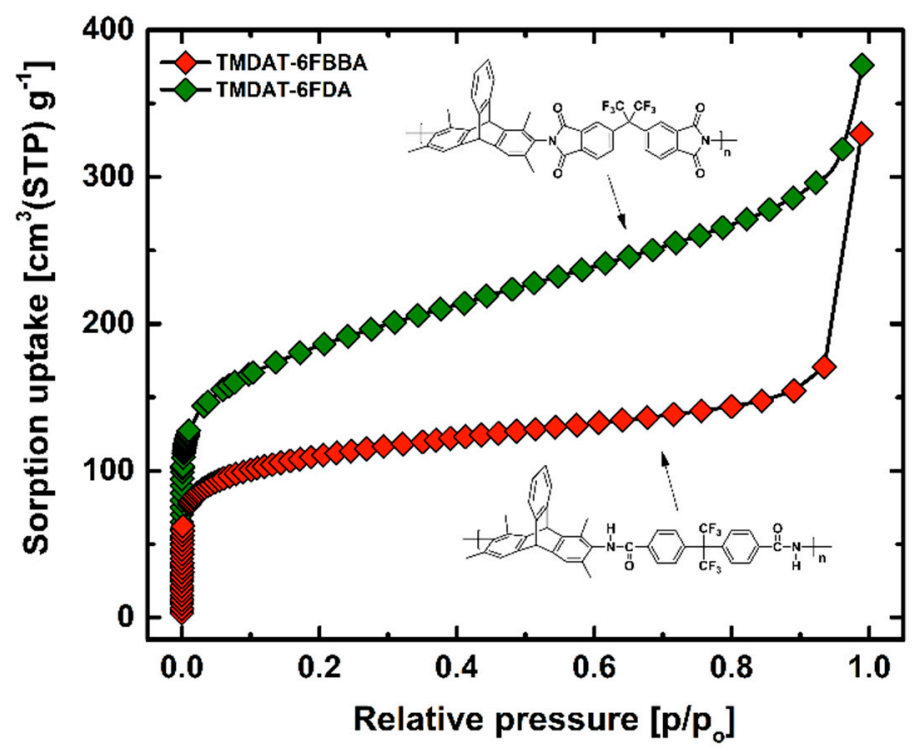

Figure 6. $\mathrm{N}_{2}$ sorption isotherms at $77 \mathrm{~K}$ of the 6FBBA-TMDAT polyamide and 6FDA-TMDAT polyimide [45]. 
The WXRD spectrum of the 6FBBA-TMDAT polyamide is shown in Figure 7; several amorphous peaks with two overlapping amorphous halos with an average chain spacing of 8.0 and $5.95 \AA$, respectively, can be observed. Also, three additional peaks located around 4.7, 3.5, and $2.1 \AA$ were identified. The two main peaks with large chain spacing derive from the introduction of the bulky triptycene building block in the polymer repeat unit. The weak amorphous peak at about $2.1 \AA$ could be an indication of the occurrence of strong interchain interactions between the amide sites through hydrogen bonding. A similar peak was also found for the triptycene based polyimide with hydroxyl-functionalized diphenyl-hexafluoropropane unit [59], where-OH group interchain hydrogen bonding was attributed to the formation of this high-angle amorphous peak.

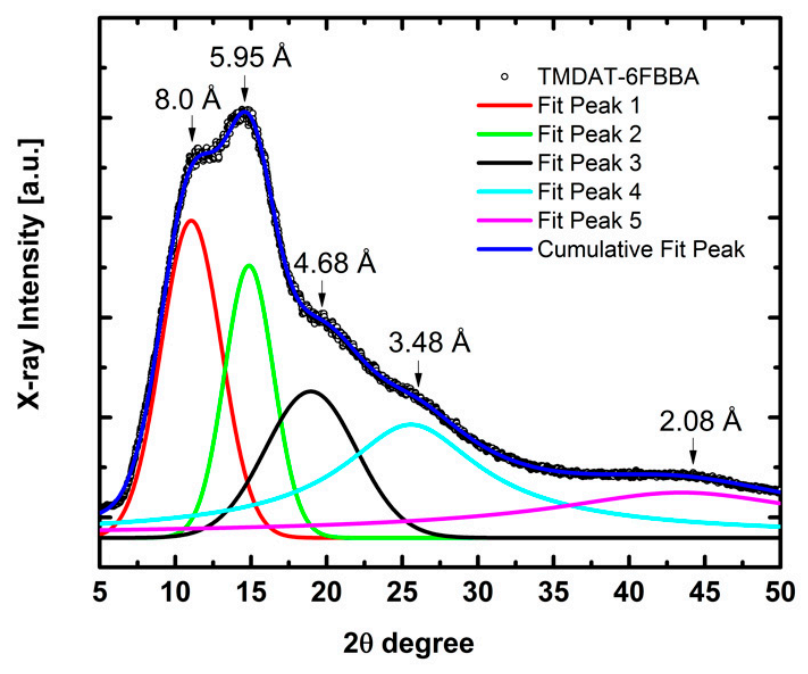

Figure 7. WXRD spectrum of 6FBBA-TMDAT polyamide and peaks deconvolution.

\subsection{Pure-Gas Sorption, Permeation, and Physical-Aging}

In this section, we describe how chemical structure, chain packing, and free volume distribution correlate with pure-gas transport properties of 6FBBA-TMDAT polyamide.

$\mathrm{CH}_{4}$ and $\mathrm{CO}_{2}$ uptakes of 6FBBA-TMDA are displayed in Figure 8a,b in the range of 0-15 atm at $35{ }^{\circ} \mathrm{C}$. In comparison with a high-free-volume polymers, such as PTMSP [60] (also plotted in Figure $8 \mathrm{a}, \mathrm{b}$ ), at pressures lower than $5 \mathrm{~atm}, 6 \mathrm{FBBA}-\mathrm{TMDAT}$ polyamide displayed higher $\mathrm{CH}_{4}$ and $\mathrm{CO}_{2}$ uptakes possibly reflecting a higher content of microporosity and ultra-microporosity-note: to reduce surface energy, gas molecules tend to sorb in small pores first. On the contrary, at pressures higher than $\sim 7 \mathrm{~atm}$ for $\mathrm{CH}_{4}$ and $\sim 14$ atm for $\mathrm{CO}_{2}$, gas sorption in PTMSP is higher than in 6FBBA-TMDAT, and this behavior agrees with the fact that PTMSP is a polymer with pore size distribution shifted towards larger micropores, i.e., in the range of $\sim 10-20 \AA ̊$ [41]. Figure $8 \mathrm{a}, \mathrm{b}$ also reveal that $\mathrm{CO}_{2}$ and $\mathrm{CH}_{4}$ uptakes in 6FBBA-TMDAT were significantly higher than in the case of low-free-volume glassy cellulose acetate (CA) [61] and polysulfone (PSF) [62] which are the most commonly used commercial gas separation materials. Interestingly, a comparison between the 6FBBA-TMDAT polyamide and CA revealed a greater $\mathrm{CO}_{2} / \mathrm{CH}_{4}$ solubility selectivity of commercial CA (Figure 8c). Note: the solubility selectivity at infinite dilution of CA was 2.7 times higher than that of 6FBBA-TMDAT. 
(a)

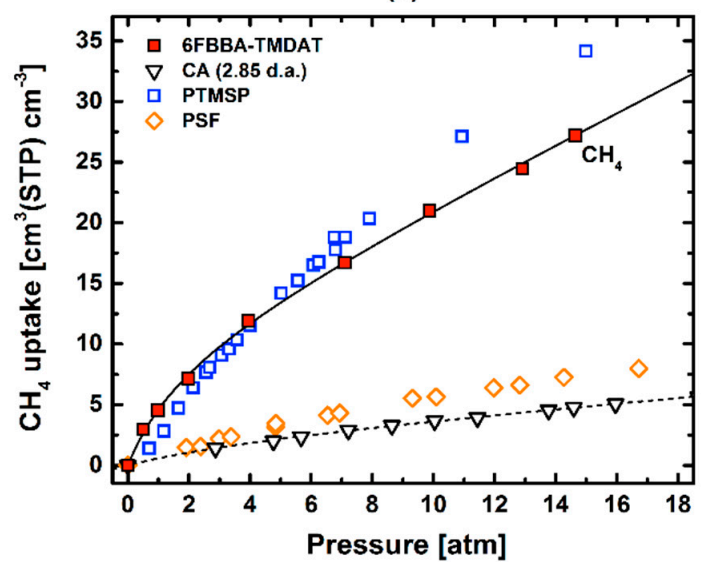

(b)

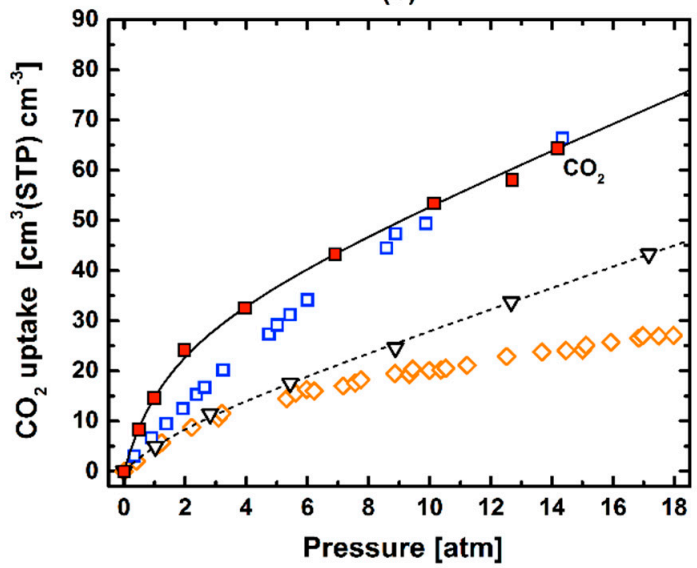

(c)

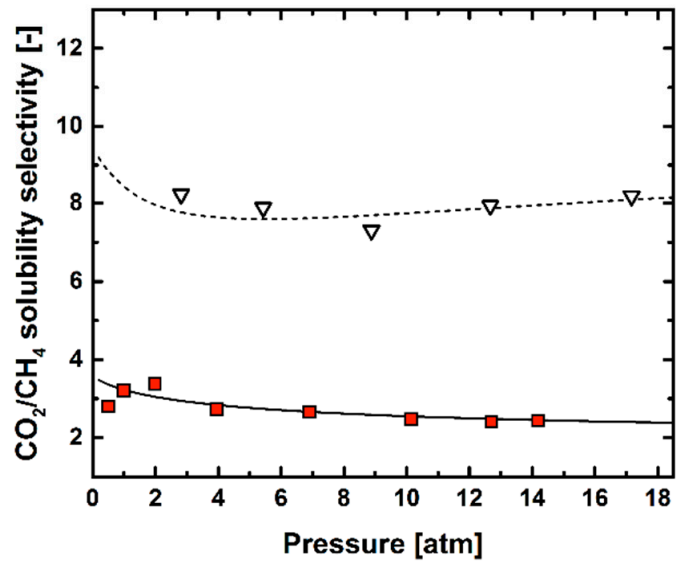

Figure 8. (a) $\mathrm{CH}_{4}$ and (b) $\mathrm{CO}_{2}$ pure-gas sorption isotherms vs. gas pressure. (c) $\mathrm{CO}_{2} / \mathrm{CH}_{4}$ pure-gas solubility selectivity of 6FBBA-TMDAT polyamide (red squares) and CA (black triangles) vs. gas pressure. Gas sorption data of polysulfone (PSF—orange diamonds) [62], poly[1 -trimethylsilyl-1-propyne] (PTMSP - blue squares) [60], and cellulose acetate (CA) [61] were digitalized from the literature. A dual-mode sorption model analysis [63] (not discussed) allowed to draw all prediction curves.

The discussion is now extended to the pure-gas permeability properties of 6FBBA-TMDAT polyamide at $35^{\circ} \mathrm{C}$. $\mathrm{He}, \mathrm{H}_{2}, \mathrm{~N}_{2}, \mathrm{O}_{2}, \mathrm{CH}_{4}$, and $\mathrm{CO}_{2}$ pure-gas permeabilities measured at $2 \mathrm{~atm}$ are listed in Table 2. 6FBBA-TMDTA aged for two days ('fresh' sample) exhibited noteworthy gas permeabilities, e.g., 226, 144, and 33 barrer for $\mathrm{H}_{2}, \mathrm{CO}_{2}$, and $\mathrm{O}_{2}$, respectively. Pure-gas permeability of 6FBBA-TMDAT increased in the following order: $\mathrm{H}_{2}>\mathrm{He}>\mathrm{CO}_{2}>\mathrm{O}_{2}>\mathrm{N}_{2}>\mathrm{CH}_{4}$. The fresh 6FBBA-TMDAT polyamide film had moderately high permselectivities, e.g., 39, 25, and 4.7 for $\mathrm{H}_{2} / \mathrm{CH}_{4}$, $\mathrm{CO}_{2} / \mathrm{CH}_{4}$ and $\mathrm{O}_{2} / \mathrm{N}_{2}$, respectively.

Because extensive hydrogen bonding induces tight interchain packing and discourages chains mobility, conventional low-free-volume polyamides typically do not display significant physical aging tendency. However, in view of the high surface area exhibited by 6FBBA-TMDAT, physical aging induced some reduction of 6FBBA-TMDAT permeability (Table 2). The aging knee-i.e., the starting point of the region of quasi-steady-state permeability [44] —of 6FBBA-TMDAT appeared after $\sim 40$ days. For example, for the $\mathrm{H}_{2}-\mathrm{CH}_{4}$ gas pair, this knee can be identified at the right boundary of the highlighted region of Figure 9a; $\mathrm{CH}_{4}$ and $\mathrm{H}_{2}$ permeabilities decreased by 30 and $15 \%$ respectively, whereas $\mathrm{H}_{2} / \mathrm{CH}_{4}$ permselectivity increased by $20 \%$ from the fresh sample values. A general analysis of all studied gases revealed that the reduction of permeability (at the aging knee) from fresh sample values approximately followed a linear trend of the kinetic gas diameters (see Figure 9b). 
(a)

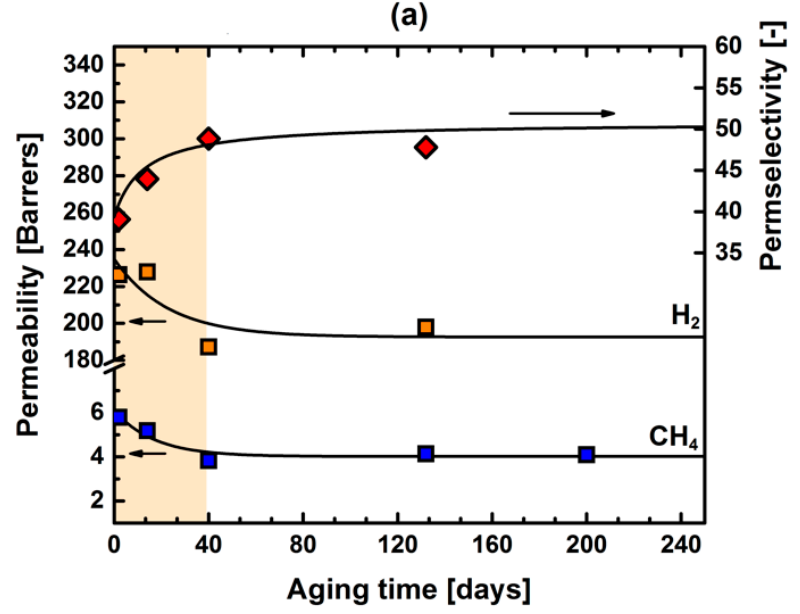

(b)

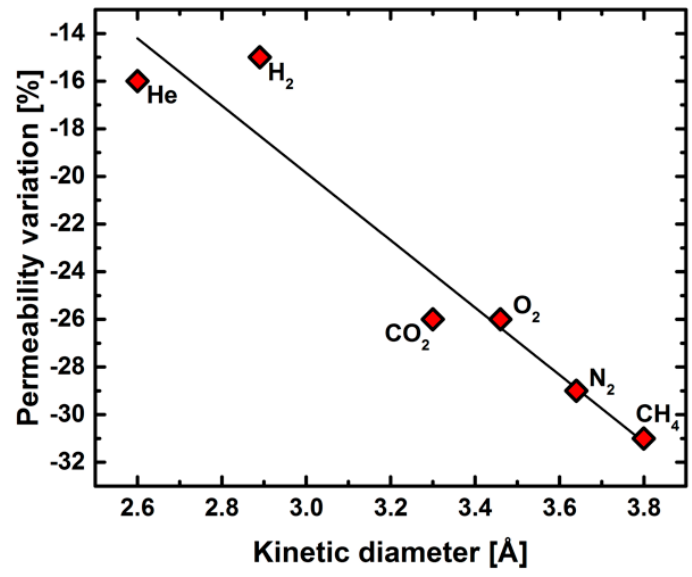

Figure 9. (a) Pure-gas permeability and permselectivity of 6FBBA-TMDAT polyamide vs. aging time $\left(\mathrm{H}_{2}-\mathrm{CH}_{4}\right.$ gas pair); (b) aging-induced permeability variation (calculated at the aging knee) vs. kinetic-gas diameter. Lines are drawn to guide the eye.

In Table 2, pure-gas permeability and permselectivity of 6FBBA-TMDAT polyamide are also compared with the structurally related 6FDA-TMDAT polyimide [45] and conventional cellulose acetate (CA, with a degree of acetylation of about 2.9 [64]). The 6FDA-TMDAT polyimide is much more permeable than 6FBBA-TMDAT polyamide because of the higher surface area (Figure 6), FFV, and chemical bond rotation freedom as discussed earlier in this work (Figures 4 and 5). For example, aged films samples of 6FBBA-TMDAT polyamide and 6FDA-TMDAT polyimide exhibited $\mathrm{CO}_{2}$ permeabilities of 109 and 1150 barrer, respectively. On the other hand, hydrogen bonding ensured higher gas-pair permselectivities for 6FBBA-TMDAT polyamide than 6FDA-TMDAT polyimide (Table 2); for example, pure-gas $\mathrm{O}_{2} / \mathrm{N}_{2}$ and $\mathrm{CO}_{2} / \mathrm{CH}_{4}$ selectivities (4.8 and 26) of aged 6FBBA-TMDA were more than $\sim 30 \%$ and $\sim 70 \%$ higher than those of its polyimide counterpart 6FDA-TMDAT (3.7 and 15), respectively. Likewise, $\mathrm{H}_{2} / \mathrm{CH}_{4}$ and $\mathrm{H}_{2} / \mathrm{N}_{2}$ pure-gas permselectivity of 6 FBBA-TMDA was 3.8 and 2.3 fold greater than 6FDA-TMDAT (at the aging knee), respectively, as shown in Figure 10 and Table 2. The good combination of both permeability and permselectivity of 6FBBA-TMDAT in both fresh and aged samples placed it close to the $2008 \mathrm{H}_{2} / \mathrm{CH}_{4}$ (Figure 10) and $\mathrm{H}_{2} / \mathrm{N}_{2}$ (not shown) upper bounds.

Compared to conventional low-free-volume glassy polymers, such as CA, 6FBBA-TMDAT demonstrated (Table 2) much higher permeability (e.g., $\sim 9$ and $\sim 16$ times higher for $\mathrm{H}_{2}$ and $\mathrm{CO}_{2}$ permeability, respectively) because of both higher solubility and diffusion coefficients (see Table 3 for the $\mathrm{CO}_{2}-\mathrm{CH}_{4}$ pure-gas pair at $2 \mathrm{~atm}$ and $35^{\circ} \mathrm{C}$ ). However, enhancement in permeability coupled with a decrease in permselectivity followed the traditional permeability/selectivity trade-off relationship. As a result, CA is generally more permselective than 6FBBA-TMDAT (Table 2). For the $\mathrm{CO}_{2}-\mathrm{CH}_{4}$ pure-gas system, the data in Table 3 indicate that the permselectivity in CA benefitted from the above mentioned solubility selectivity advantage (Figure 8c); whereas 6FBBA-TMDAT polyamide fills this solubility selectivity gap by a superior diffusion selectivity (Table 2). 
Table 2. Aging time [days], permeability [barrer], and permselectivity of 6FBBA-TMDAT polyamide and 6FDA-TMDAT polyimide [45] films for pure gases at $35^{\circ} \mathrm{C}$ and $2 \mathrm{~atm}$; the conventional commercial cellulose acetate (CA) [61] is also listed for comparison.

\begin{tabular}{|c|c|c|c|c|c|c|c|c|c|c|}
\hline & Aging & $\mathrm{He}$ & $\mathrm{H}_{2}$ & $\mathbf{N}_{2}$ & $\mathrm{O}_{2}$ & $\mathrm{CH}_{4}$ & $\mathrm{CO}_{2}$ & $\mathrm{H}_{2} / \mathrm{CH}_{4}$ & $\mathrm{O}_{2} / \mathrm{N}_{2}$ & $\mathrm{CO}_{2} / \mathrm{CH}_{4}$ \\
\hline Polymer & [days] & \multicolumn{6}{|c|}{ Pure-Gas Permeability [barrer] } & \multicolumn{3}{|c|}{ Ideal Selectivity [-] } \\
\hline 6FBBA-TMDAT [This work] & 2 & 185 & 226 & 7.1 & 33 & 5.8 & 144 & 39 & 4.7 & 25 \\
\hline 6FBBA-TMDAT [This work] & 14 & 178 & 228 & 6.4 & 30 & 5.2 & 133 & 44 & 4.8 & 26 \\
\hline 6FBBA-TMDAT [This work] & 40 & 150 & 187 & 4.8 & 24 & 3.8 & 105 & 49 & 4.9 & 27 \\
\hline 6FBBA-TMDAT [This work] & 132 & 160 & 198 & 5.2 & 25 & 4.1 & 109 & 48 & 4.8 & 26 \\
\hline 6FDA-TMDAT [45] & fresh & 758 & 1400 & 113 & 374 & 121 & 1727 & 12 & 3.3 & 14 \\
\hline 6FDA-TMDAT [45] & 200 & 601 & 1024 & 70 & 261 & 76 & 1150 & 13 & 3.7 & 15 \\
\hline CA (D.S. 2.84) [61] & fresh & 20 & 16 & 0.2 & 1.5 & 0.2 & 6.6 & 80 & 6.3 & 33 \\
\hline
\end{tabular}

Table 3. $\mathrm{CO}_{2}$ and $\mathrm{CH}_{4}$ pure-gas solubility (S, measured gravimetrically) and diffusion coefficients (D), together with $\mathrm{CO}_{2} / \mathrm{CH}_{4}$ solubility selectivity, and $\mathrm{CO}_{2} / \mathrm{CH}_{4}$ diffusivity selectivity $\left(2 \mathrm{~atm}\right.$ and $\left.35^{\circ} \mathrm{C}\right)$ for 6FBBA-TMDAT polyamide and CA [64]. Diffusion coefficients were calculated from $D=P / S$.

\begin{tabular}{|c|c|c|c|c|c|c|}
\hline & $\mathrm{S}, \mathrm{CH}_{4}$ & $\mathrm{~S}, \mathrm{CO}_{2}$ & $\mathrm{D}, \mathrm{CH}_{4}$ & $\mathrm{D}, \mathrm{CO}_{2}$ & \multirow{2}{*}{$\frac{\alpha_{S}}{[-]}$} & \multirow{2}{*}{$\frac{\alpha_{D}}{[-]}$} \\
\hline Polymer & \multicolumn{2}{|c|}{$\left[\mathrm{cm}^{3}(\mathrm{STP}) \mathrm{cm}^{-3} \mathrm{~atm}^{-1}\right]$} & \multicolumn{2}{|c|}{$\left[\mathrm{cm}^{2} \mathrm{~s}^{-1}\right]$} & & \\
\hline 6FBBA-TMDAT [This work] & 3.6 & 12.2 & $9.1 \times 10^{-9}$ & $7.1 \times 10^{-8}$ & 3.4 & 7.8 \\
\hline CA (D.S. 2.84) [61] & 0.5 & 4.2 & $5.1 \times 10^{-9}$ & $1.8 \times 10^{-8}$ & 8.1 & 3.5 \\
\hline
\end{tabular}




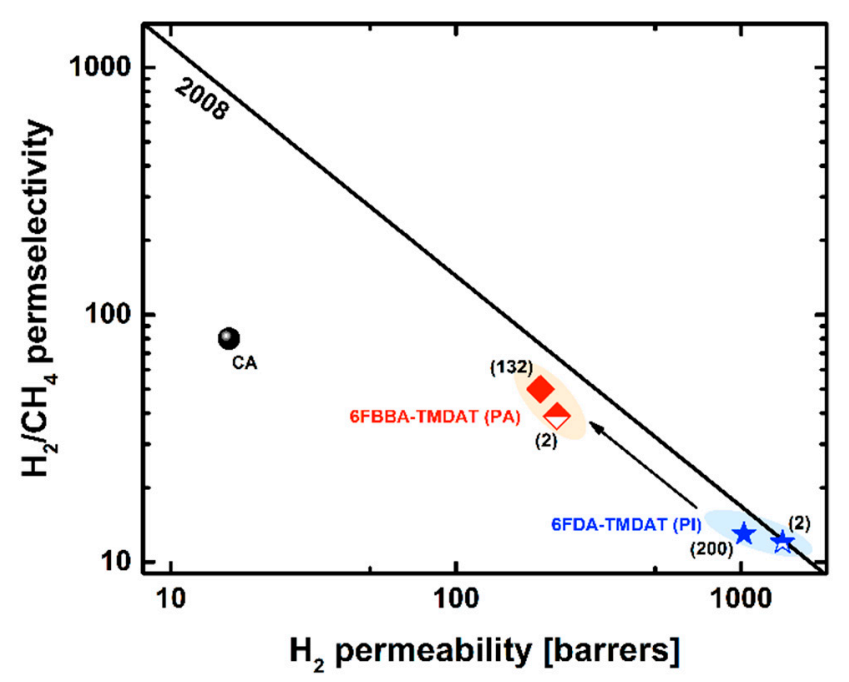

Figure 10. Location of 6FBBA-TMDAT polyamide on pure-gas $\mathrm{H}_{2}-\mathrm{CH}_{4}$ upper bound (2008) plot [65]. Cellulose acetate (CA) [64] and 6FDA-TMDAT [45] are shown for comparison. Aging (closed symbols) was recorded for 132 and 200 days for 6FBBA-TMDAT (polyamide) and 6FDA-TMDAT (polyimide), respectively (as also indicated in the plot).

\section{3. $\mathrm{CO}_{2}-\mathrm{CH}_{4}$ Mixed-Gas Permeation}

The 6FBBA-TMDAT film was also tested for mixed-gas permeation of a 50:50 $\mathrm{mol} \% \mathrm{CO}_{2}: \mathrm{CH}_{4}$ mixture up to $30 \mathrm{~atm}$ total feed pressure (at $35^{\circ} \mathrm{C}$ ). As shown in Figure $11 \mathrm{a}, \mathrm{CO}_{2}$ pure-gas permeability decreased with increasing pressure, due to the saturation of Langmuir's sites. On the other hand, $\mathrm{CO}_{2}-\mathrm{CH}_{4}$ competitive sorption was responsible for the decrease of $\mathrm{CO}_{2}$ mixed-gas permeability from the pure-gas values (Figure 11a). In the range of studied pressures, both pure- and mixed-gas $\mathrm{CO}_{2}$ permeability isotherms did not reveal a minimum and the subsequent positive slope that generally marks the occurrence of plasticization. In other words, the occurance of plasticization hides behind the effects on gas permeability of saturation of Langmuir's sorption sites and competitive sorption. Although in a different range of permeability, pure- and mixed-gas $\mathrm{CO}_{2}$ permeability of $6 \mathrm{FBBA}-\mathrm{TMDAT}$ followed the general behavior trends of CA [64] (Figure 11a).

For both 6FBBA-TMDAT and CA, pure-gas $\mathrm{CH}_{4}$ permeability decreased slightly with pressure, due to Langmuir's sites saturation (Figure 11b). Contrarily to the just described permeation behavior of $\mathrm{CO}_{2}$ in the mixture, $\mathrm{CH}_{4}$ mixed-gas permeability of both 6FBBA-TMDAT and CA increased with partial pressure. Experimental studies on $\mathrm{CO}_{2}-\mathrm{CH}_{4}$ pure- and mixed-gas permeability, sorption and diffusion in glassy polyimide and rubbery polydimethylsiloxane membranes $[66,67]$ showed that this $\mathrm{CH}_{4}$ permeability enhancement is directly correlated to $\mathrm{CO}_{2}$ sorption; i.e., increasing $\mathrm{CO}_{2}$ content in the polymer matrix activates chain mobility thus boosting $\mathrm{CH}_{4}$ diffusion coefficient. Hence, the occurrence of this phenomenon explains the decrease in $\mathrm{CO}_{2} / \mathrm{CH}_{4}$ permselectivity under mixed-gas conditions in both 6FBBA-TMDAT and CA (Figure 11c).

Finally, it is noteworthy that at 10 atm partial $\mathrm{CO}_{2}$ pressure (the typical well-head pressure of interest for natural gas applications [68]), the increase in mixed-gas $\mathrm{CH}_{4}$ permeability from the corresponding pure-gas values was $2 \%$ and $43 \%$ for CA and 6FBBA-TMDAT, respectively. Consequently, 6FBBA-TMDAT suffered a considerable loss in $\mathrm{CO}_{2} / \mathrm{CH}_{4}$ mixed-gas permselectivity compared to CA. This is most likely, due to the fact that the hydrogen-bonding ability of 6FBBA-TMDAT was sterically reduced by the presence of the bulky triptycene building block (Figure 1). 
(a)

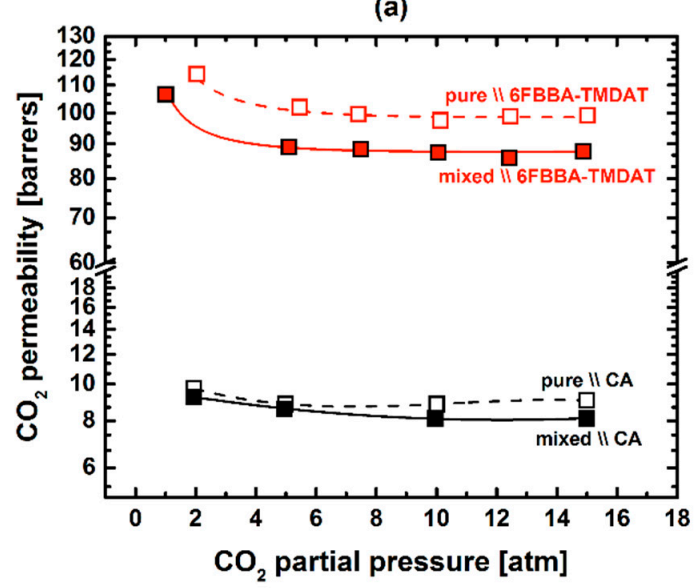

(b)

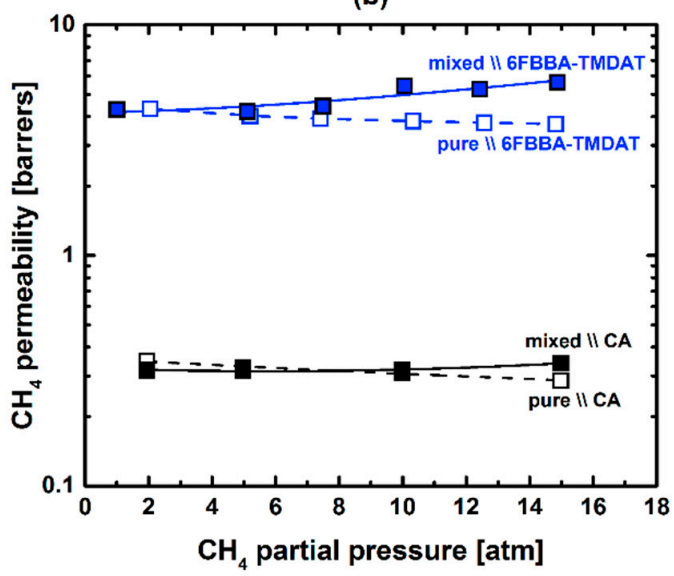

(c)

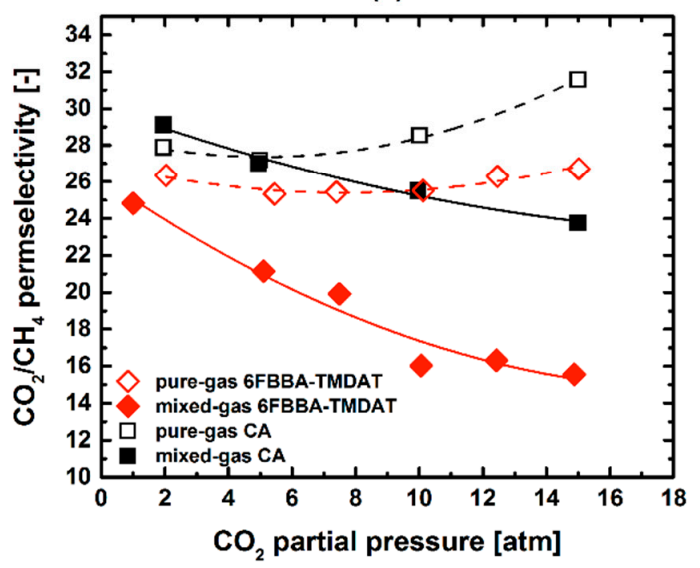

Figure 11. Experimental (a) $\mathrm{CO}_{2}$ and (b) $\mathrm{CH}_{4}$ pure- and mixed-gas permeability vs. partial gas pressure for 6FBBA-TMDAT polyamide and CA [64]. (c) pure- and mixed-gas $\mathrm{CO}_{2} / \mathrm{CH}_{4}$ permselectivity of the same polymers. Lines are drawn to guide the eye.

\section{Conclusions}

In this study, ortho-methyl tetra-substituted triptycene diamine (TMDAT) was successfully reacted with 4,4'-(hexafluoroisopropylidene)bis(benzoic acid) (6FBBA) to form 6FBBA-TMDAT polyamide. The polymer was soluble in aprotic solvents, such as DMAc, and exhibited excellent thermal stability $\left(\sim 480{ }^{\circ} \mathrm{C}\right)$. The BET surface area of the aromatic polyamide was $396 \mathrm{~m}^{2} \mathrm{~g}^{-1}$ confirming that it is an example of a polyamide of intrinsic microporosity (PIM-PA). 6FBBA-TMDAT displayed high pure-gas permeabilities and moderate permselectivities, which placed it close to the $2008 \mathrm{H}_{2} / \mathrm{CH}_{4}$ and $\mathrm{H}_{2} / \mathrm{N}_{2}$ upper bounds. Compared to its polyimide counterpart 6FDA-TMDAT, 6FBBA-TMDAT exhibited a tighter structure and therefore improved permselectivities toward various gas pairs at cost of lower permeability. Because in 6FBBA-TMDAT the bulky triptycene unit 'protects' the amide $\mathrm{H}$-bonding sites, some degree of physical aging was observed. The same effect was also accountable for the lower plasticization resistance of 6FBBA-TMDAT than conventional cellulose acetate used for membrane-based $\mathrm{CO}_{2} / \mathrm{CH}_{4}$ separation. The mixed-gas $\mathrm{CO}_{2} / \mathrm{CH}_{4}$ permselectivity of $6 \mathrm{FBBA}-\mathrm{TMDAT}$ at $35^{\circ} \mathrm{C}$ was depressed, due to the increase of $\mathrm{CH}_{4}$ mixed-gas diffusion associated with $\mathrm{CO}_{2}$ sorption.

Author Contributions: Conceptualization, B.S.G. and I.P.; investigation, G.G.; data acquisition, G.G., B.S.G. and Y.W.; writing and original draft preparation, G.G.; review and editing, Y.W., B.S.G. and I.P.; polymer synthesis, B.S.G.

Funding: This work was supported by funding (BAS/1/1323-01-01) from King Abdullah University of Science and Technology (KAUST).

Conflicts of Interest: The authors declare no conflict of interest. 


\section{References}

1. Mera, H.; Takata, T. High-performance fibers. In Ullmann's Encyclopedia of Industrial Chemistry; Wiley-VCH Verlag GmbH \& Co. KGaA: Weinheim, Germany, 2000.

2. Loeb, S.; Sourirajan, S. Sea water demineralization by means of an osmotic membrane. In Saline Water Conversion II; Gould, R.F., Ed.; American Chemical Society: Washington, DC, USA, 1963; Volume 38, pp. 117-132.

3. Baker, R.W. Reverse osmosis. In Membrane Technology and Applications, 3rd ed.; Baker, R.W., Ed.; John Wiley and Sons: Hoboken, NJ, USA, 2012.

4. Qian, H.; Zheng, J.; Zhang, S. Preparation of microporous polyamide networks for carbon dioxide capture and nanofiltration. Polymer 2013, 54, 557-564. [CrossRef]

5. Zulfiqar, S.; Sarwar, M.I. Exploring aramid as emerging contender for $\mathrm{CO}_{2}$ capture. Chin. J. Chem. Eng. 2016, 24, 850-855. [CrossRef]

6. Zhou, H.; Tao, F.; Liu, Q.; Zong, C.; Yang, W.; Cao, X.; Jin, W.; Xu, N. Microporous polyamide membranes for molecular sieving of nitrogen from volatile organic compounds. Angew. Chem. Int. Ed. 2017, 56, 5755-5759. [CrossRef] [PubMed]

7. McKeown, N.B.; Budd, P.M. Polymers of intrinsic microporosity (PIMs): Organic materials for membrane separations, heterogeneous catalysis and hydrogen storage. Chem. Soc. Rev. 2006, 35, 675-683. [CrossRef] [PubMed]

8. Budd, P.M.; Ghanem, B.S.; Makhseed, S.; McKeown, N.B.; Msayib, K.J.; Tattershall, C.E. Polymers of intrinsic microporosity (PIMs): Robust, solution-processable, organic nanoporous materials. Chem. Commun. 2004, 230-231. [CrossRef] [PubMed]

9. Weber, J.; Su, Q.; Antonietti, M.; Thomas, A. Exploring polymers of intrinsic microporosity - microporous, soluble polyamide and polyimide. Macromol. Rapid Commun. 2007, 28, 1871-1876. [CrossRef]

10. Ding, S.-Y.; Wang, W. Covalent organic frameworks (COFs): From design to applications. Chem. Soc. Rev. 2013, 42, 548-568. [CrossRef] [PubMed]

11. Zhu, Y.; Yang, H.; Jin, Y.; Zhang, W. Porous poly(aryleneethynylene) networks through alkyne metathesis. Chem. Mater. 2013, 25, 3718-3723. [CrossRef]

12. Ben, T.; Qiu, S. Porous aromatic frameworks: Synthesis, structure and functions. CrystEngComm 2013, 15, 17-26. [CrossRef]

13. Xu, Y.; Jin, S.; Xu, H.; Nagai, A.; Jiang, D. Conjugated microporous polymers: Design, synthesis and application. Chem. Soc. Rev. 2013, 42, 8012-8031. [CrossRef]

14. Tan, L.; Tan, B. Hypercrosslinked porous polymer materials: Design, synthesis, and applications. Chem. Soc. Rev. 2017, 46, 3322-3356. [CrossRef] [PubMed]

15. Matteucci, S.; Yampolskii, Y.; Freeman, B.D.; Pinnau, I. Transport of gases and vapors in glassy and rubbery polymers. In Materials Science of Membranes for Gas and Vapor Separation; Yampolskii, Y., Freeman, B.D., Pinnau, I., Eds.; Wiley: Chichester, UK, 2006.

16. Espeso, J.; Lozano, A.E.; de la Campa, J.G.; de Abajo, J. Effect of substituents on the permeation properties of polyamide membranes. J. Membr. Sci. 2006, 280, 659-665. [CrossRef]

17. Díez, B.; Cuadrado, P.; Marcos-Fernández, Á.; Prádanos, P.; Tena, A.; Palacio, L.; Lozano, Á.E.; Hernández, A. Helium recovery by membrane gas separation using poly(o-acyloxyamide)s. Ind. Eng. Chem. Res. 2014, 53, 12809-12818. [CrossRef]

18. de Abajo, J.; de la Campa, J.G.; Lozano, A.E. Designing aromatic polyamides and polyimides for gas separation membranes. Macromol. Symp. 2003, 199, 293-306. [CrossRef]

19. Santiago-Garcia, J.L.; Pérez-Francisco, J.M.; Zolotukhin, M.G.; Vázquez-Torres, H.; Aguilar-Vega, M.; González-Díaz, M.O. Gas transport properties of novel aromatic poly- and copolyamides bearing bulky functional groups. J. Membr. Sci. 2017, 522, 333-342. [CrossRef]

20. Morisato, A.; Ghosal, K.; Freeman, B.D.; Chern, R.T.; Alvarez, J.C.; de la Campa, J.G.; Lozano, A.E.; de Abajo, J. Gas separation properties of aromatic polyamides containing hexafluoroisopropylidene groups. J. Membr. Sci. 1995, 104, 231-241. [CrossRef]

21. Calle, M.; Lozano, A.E.; de Abajo, J.; de la Campa, J.G.; Álvarez, C. Design of gas separation membranes derived of rigid aromatic polyimides. 1. Polymers from diamines containing di-tert-butyl side groups. J. Membr. Sci. 2010, 365, 145-153. [CrossRef] 
22. Carrera-Figueiras, C.; Aguilar-Vega, M. Gas permeability and selectivity of hexafluoroisopropylidene aromatic isophthalic copolyamides. J. Polym. Sci. Part B Polym. Phys. 2005, 43, 2625-2638. [CrossRef]

23. Guzmán-Lucero, D.; Palomeque-Santiago, J.; Camacho-Zúñiga, C.; Ruiz-Treviño, F.; Guzmán, J.; Galicia-Aguilar, A.; Aguilar-Lugo, C. Gas permeation properties of soluble aromatic polyimides based on 4-fluoro-4,4'-diaminotriphenylmethane. Materials 2015, 8, 1951-1965. [CrossRef]

24. López-Nava, R.; Vázquez-Moreno, F.S.; Palí-Casanova, R.; Aguilar-Vega, M. Gas permeability coefficients of isomeric aromatic polyamides obtained from $4,4^{\prime}$-(9-fluorenylidene) diamine and aromatic diacid chlorides. Polym. Bull. 2002, 49, 165-172. [CrossRef]

25. Plaza-Lozano, D.; Comesaña-Gándara, B.; de la Viuda, M.; Seong, J.G.; Palacio, L.; Prádanos, P.; de la Campa, J.G.; Cuadrado, P.; Lee, Y.M.; Hernández, A.; et al. New aromatic polyamides and polyimides having an adamantane bulky group. Mater. Today Commun. 2015, 5, 23-31. [CrossRef]

26. Bisoi, S.; Bandyopadhyay, P.; Bera, D.; Banerjee, S. Effect of bulky groups on gas transport properties of semifluorinated poly(ether amide)s containing pyridine moiety. Eur. Polym. J. 2015, 66, 419-428. [CrossRef]

27. Bandyopadhyay, P.; Banerjee, S. Spiro[fluorene-9,9'-xanthene] containing fluorinated poly(ether amide)s: Synthesis, characterization and gas transport properties. Eur. Polym. J. 2015, 69, 140-155. [CrossRef]

28. Bera, D.; Bandyopadhyay, P.; Ghosh, S.; Banerjee, S.; Padmanabhan, V. Highly gas permeable aromatic polyamides containing adamantane substituted triphenylamine. J. Membr. Sci. 2015, 474, 20-31. [CrossRef]

29. Bera, D.; Bandyopadhyay, P.; Ghosh, S.; Banerjee, S. Gas transport properties of aromatic polyamides containing adamantyl moiety. J. Membr. Sci. 2014, 453, 175-191. [CrossRef]

30. Bisoi, S.; Mandal, A.K.; Padmanabhan, V.; Banerjee, S. Aromatic polyamides containing trityl substituted triphenylamine: Gas transport properties and molecular dynamics simulations. J. Membr. Sci. 2017, 522, 77-90. [CrossRef]

31. Bera, D.; Padmanabhan, V.; Banerjee, S. Highly gas permeable polyamides based on substituted triphenylamine. Macromolecules 2015, 48, 4541-4554. [CrossRef]

32. Bandyopadhyay, P.; Bera, D.; Banerjee, S. Synthesis, characterization and gas transport properties of semifluorinated new aromatic polyamides. Sep. Purif. Technol. 2013, 104, 138-149. [CrossRef]

33. Bandyopadhyay, P.; Bera, D.; Ghosh, S.; Banerjee, S. Di-tert-butyl containing semifluorinated poly(ether amide)s: Synthesis, characterization and gas transport properties. J. Membr. Sci. 2013, 447, 413-423. [CrossRef]

34. Budd, P.M.; Elabas, E.S.; Ghanem, B.S.; Makhseed, S.; McKeown, N.B.; Msayib, K.J.; Tattershall, C.E.; Wang, D. Solution-processed, organophilic membrane derived from a polymer of intrinsic microporosity. Adv. Mater. 2004, 16, 456-459. [CrossRef]

35. Budd, P.M.; Msayib, K.J.; Tattershall, C.E.; Ghanem, B.S.; Reynolds, K.J.; McKeown, N.B.; Fritsch, D. Gas separation membranes from polymers of intrinsic microporosity. J. Membr. Sci. 2005, 251, 263-269. [CrossRef]

36. Low, Z.-X.; Budd, P.M.; McKeown, N.B.; Patterson, D.A. Gas permeation properties, physical aging, and its mitigation in high free volume glassy polymers. Chem. Rev. 2018, 118, 5871-5911. [CrossRef] [PubMed]

37. Wang, Y.; Ma, X.; Ghanem, B.S.; Alghunaimi, F.; Pinnau, I.; Han, Y. Polymers of intrinsic microporosity for energy-intensive membrane-based gas separations. Mater. Today Nano 2018, 3, 69-95. [CrossRef]

38. Swaidan, R.; Ghanem, B.; Pinnau, I. Fine-tuned intrinsically ultramicroporous polymers redefine the permeability/selectivity upper bounds of membrane-based air and hydrogen separations. ACS Macro Lett. 2015, 4, 947-951. [CrossRef]

39. Ding, Y.; Bikson, B. Soluble aromatic polyamides containing the phenylindane group and their gas transport characteristics. Polymer 2002, 43, 4709-4714. [CrossRef]

40. Bisoi, S.; Mandal, A.K.; Singh, A.S.B.; Banerjee, S. Gas separation properties of Troeger's base-bridged polyamides. e-Polymers 2017, 27, 283-293. [CrossRef]

41. Ghanem, B.S.; Swaidan, R.; Litwiller, E.; Pinnau, I. Ultra-microporous triptycene-based polyimide membranes for high-performance gas separation. Adv. Mater. 2014, 26, 3688-3692. [CrossRef]

42. Carta, M.; Croad, M.; Malpass-Evans, R.; Jansen, J.C.; Bernardo, P.; Clarizia, G.; Friess, K.; Lanč, M.; McKeown, N.B. Triptycene induced enhancement of membrane gas selectivity for microporous Tröger's base polymers. Adv. Mater. 2014, 26, 3526-3531. [CrossRef]

43. Zhang, C.; Liu, Y.; Li, B.; Tan, B.; Chen, C.-F.; Xu, H.-B.; Yang, X.-L. Triptycene-based microporous polymers: Synthesis and their gas storage properties. ACS Macro Lett. 2012, 1, 190-193. [CrossRef] 
44. Swaidan, R.; Al-Saeedi, M.; Ghanem, B.; Litwiller, E.; Pinnau, I. Rational design of intrinsically ultramicroporous polyimides containing bridgehead-substituted triptycene for highly selective and permeable gas separation membranes. Macromolecules 2014, 47, 5104-5114. [CrossRef]

45. Ghanem, B.S.; Alghunaimi, F.; Wang, Y.; Genduso, G.; Pinnau, I. Synthesis of highly gas-permeable polyimides of intrinsic microporosity derived from 1,3,6,8-tetramethyl-2,7-diaminotriptycene. ACS Omega 2018, 3, 11874-11882. [CrossRef]

46. Chen, C.-F.; Ma, Y.-X. Synthesis and reactions of triptycenes and their derivatives. In Iptycenes Chemistry: From Synthesis to Applications; Springer: Berlin/Heidelberg, Germany, 2013; pp. 13-77.

47. Alghunaimi, F.; Ghanem, B.; Alaslai, N.; Swaidan, R.; Litwiller, E.; Pinnau, I. Gas permeation and physical aging properties of iptycene diamine-based microporous polyimides. J. Membr. Sci. 2015, 490, 321-327. [CrossRef]

48. Hoffmeister, E.; Kropp, J.E.; McDowell, T.L.; Michel, R.H.; Rippie, W.L. Triptycene polymers. J. Polym. Sci. Part A-1 Polym. Chem. 1969, 7, 55-72. [CrossRef]

49. Kasashima, Y.; Kaneda, T.; Akutsu, F.; Naruchi, K.; Miura, M. Synthesis and properties of aromatic polyamides and polyimides from 9, 10-dihydro-9,10-o-benzenoanthracene-1,4-diamine. Polym. J. 1994, 26, 1179-1185. [CrossRef]

50. Kasashima, Y.; Kaneda, T.; Saito, G.; Akutsu, F.; Naruchi, K.; Miura, M. Synthesis and properties of aromatic polyamides from 2,7-triptycenediamine. Macromol. Chem. Phys. 1994, 195, 2693-2697. [CrossRef]

51. Hsiao, S.-H.; Wang, H.-M.; Chou, J.-S.; Guo, W.; Tsai, T.-H. Synthesis and characterization of novel organosoluble and thermally stable polyamides bearing triptycene in their backbones. J. Polym. Res. 2012, 19, 9902. [CrossRef]

52. Hsiao, S.-H.; Chiu, Y.-T. Electrosynthesis and electrochromic properties of poly(amide-triarylamine)s containing triptycene units. RSC Adv. 2015, 5, 90941-90951. [CrossRef]

53. Mondal, S.; Das, N. Triptycene based organosoluble polyamides: Synthesis, characterization and study of the effect of chain flexibility on morphology. RSC Adv. 2014, 4, 61383-61393. [CrossRef]

54. Bera, R.; Mondal, S.; Das, N. Nanoporous triptycene based network polyamides (TBPs) for selective $\mathrm{CO}_{2}$ uptake. Polymer 2017, 111, 275-284. [CrossRef]

55. Luo, S.; Liu, J.; Lin, H.; Kazanowska, B.A.; Hunckler, M.D.; Roeder, R.K.; Guo, R. Preparation and gas transport properties of triptycene-containing polybenzoxazole (PBO)-based polymers derived from thermal rearrangement (TR) and thermal cyclodehydration (TC) processes. J. Mater. Chem. A 2016, 4, 17050-17062. [CrossRef]

56. Ellison, H.; Hey, D.H. The action of benzaldehyde on $o_{-}^{-}, m-$, and $p$-xylene in the presence of aluminium chloride. J. Chem. Soc. (Resumed) 1938, 1847-1853. [CrossRef]

57. Yamazaki, N.; Matsumoto, M.; Higashi, F. Studies on reactions of the n-phosphonium salts of pyridines. XIV. Wholly aromatic polyamides by the direct polycondensation reaction by using phosphites in the presence of metal salts. J. Polym. Sci. Polym. Chem. Ed. 1975, 13, 1373-1380. [CrossRef]

58. O’Brien, K.C.; Koros, W.J.; Barbari, T.A.; Sanders, E.S. A new technique for the measurement of multicomponent gas transport through polymeric films. J. Membr. Sci. 1986, 29, 229-238. [CrossRef]

59. Alghunaimi, F.; Ghanem, B.; Alaslai, N.; Mukaddam, M.; Pinnau, I. Triptycene dimethyl-bridgehead dianhydride-based intrinsically microporous hydroxyl-functionalized polyimide for natural gas upgrading. J. Membr. Sci. 2016, 520, 240-246. [CrossRef]

60. Vopička, O.; De Angelis, M.G.; Sarti, G.C. Mixed gas sorption in glassy polymeric membranes: $\mathrm{I} . \mathrm{CO}_{2} / \mathrm{CH}_{4}$ and $n-\mathrm{C}_{4} / \mathrm{CH}_{4}$ mixtures sorption in poly(1-trimethylsilyl-1-propyne) (PTMSP). J. Membr. Sci. 2014, 449, 97-108. [CrossRef]

61. Puleo, A.C.; Paul, D.R.; Kelley, S.S. The effect of degree of acetylation on gas sorption and transport behavior in cellulose acetate. J. Membr. Sci. 1989, 47, 301-332. [CrossRef]

62. Erb, A.J.; Paul, D.R. Gas sorption and transport in polysulfone. J. Membr. Sci. 1981, 8, 11-22. [CrossRef]

63. Koros, W.J.; Chan, A.H.; Paul, D.R. Sorption and transport of various gases in polycarbonate. J. Membr. Sci. 1977, 2, 165-190. [CrossRef]

64. Swaidan, R.; Ghanem, B.; Al-Saeedi, M.; Litwiller, E.; Pinnau, I. Role of intrachain rigidity in the plasticization of intrinsically microporous triptycene-based polyimide membranes in mixed-gas $\mathrm{CO}_{2} / \mathrm{CH}_{4}$ separations. Macromolecules 2014, 47, 7453-7462. [CrossRef]

65. Robeson, L.M. The upper bound revisited. J. Membr. Sci. 2008, 320, 390-400. [CrossRef] 
66. Genduso, G.; Ghanem, B.S.; Pinnau, I. Experimental mixed-gas permeability, sorption and diffusion of $\mathrm{CO}_{2}-\mathrm{CH}_{4}$ mixtures in 6FDA-mPDA polyimide membrane: Unveiling the effect of competitive sorption on permeability selectivity. Membranes 2019, 9, 10. [CrossRef] [PubMed]

67. Genduso, G.; Litwiller, E.; Ma, X.; Zampini, S.; Pinnau, I. Mixed-gas sorption in polymers via a new barometric test system: Sorption and diffusion of $\mathrm{CO}_{2}-\mathrm{CH}_{4}$ mixtures in polydimethylsiloxane (PDMS). J. Membr. Sci. 2019. [CrossRef]

68. Baker, R.W. Future directions of membrane gas separation technology. Ind. Eng. Chem. Res. 2002, 41, 1393-1411. [CrossRef]

(C) 2019 by the authors. Licensee MDPI, Basel, Switzerland. This article is an open access article distributed under the terms and conditions of the Creative Commons Attribution (CC BY) license (http://creativecommons.org/licenses/by/4.0/). 